\title{
The impacts of control, racism, and colonialism on contemporary Aboriginal-police relations
}

\author{
Joshua Green
}

University of Technology Sydney, Faculty of Arts and Social Sciences, PO Box 123, Ultimo NSW 2007, Australia. joshua.z.green@student.uts.edu.au

\begin{abstract}
Many Aboriginal and Torres Strait Islander peoples are still treated differently in their interactions with the police. By analysing the histories of the New South Wales Police Force, policy, and Indigenous affairs, this essay seeks to analyse the multifaceted factors which have given rise to contemporary Aboriginal police relations.
\end{abstract}

Key words: RCIADIC; NSWPF; Aboriginal-police relations; colonialism

Police harassment had a significant role in politicising all of us... I've always said that the beginning of my political education was when I got a good kicking from a bunch of thug coppers in the Regent Street Police Station in Redfern.

- Dr Gary Foley.

The police hated us and that was the excuse. They caught us defending ourselves, they would take us to the cells and flog us. The cells were called the abattoirs. The cells were covered with Aboriginal blood.

- Prof Marcia Langton.

Excerpts from The Redfern Story (Johnson 2014)

For as long as the New South Wales Police Force and the parts from which it was conglomerated have existed, these bodies have exercised control over Aboriginal and Torres Strait Islander peoples in this state. This is to say, on the pseudoscientific basis of race, police organisations which stretch back to early colonial inceptions have operated in ways which have been expressed as patriarchal dominance over Aboriginal people, to the extent that deep and complex impacts permeate contemporary Aboriginal-police relations. Police interactions 
with Aboriginal people led in part to the establishment of the Royal Commission into Aboriginal Deaths in Custody in 1987, a cornerstone in investigating this facet of Aboriginal history and its many underlying issues. However, this only came nigh on the bicentenary of invasion. Describing the structural inattention to all matters Aboriginal in 1969, WEH Stanner used the metaphor of 'a view from a window which has been carefully placed to exclude a whole quadrant of the landscape' (p. 24). What he did not mention about this window was the paternalistically blue stained-glass from which the pane was crafted - the hue of which stains the past and is refracted at present.

It is important to start with the fact that there was no professional police force in England until forty years after first contact in Sydney, which means that police forces were not replicated from the metropole in New South Wales like court systems, and there wasn't a significant background to draw upon when establishing new police bodies (Wootten 1993, p. 265). We can see that the initial police forces in New South Wales were established at a time of early contact during the construction of colonial pillars, which would explain a colonialism innate to the police forces born of that time. Further, citing Rowley (1970), Wootten suggests the role of police was to protect white settlers and rid them of 'troublesome blacks' (1993, p. 265-6). This positions police of the time not just with an innate colonial power, but as one of the prominent pillars of colonialism. Given that these forces remained until being amalgamated into the NSW Police Force in 1862 (NSWPF n.d.), it isn't hard to see the way this racist control has been woven throughout the history of the NSWPF.

\section{Protectionism, patriarchy, and paternalism}

The policy of protectionism ensured a longevity to the role of the police in NSW as controllers (HREOC 1991), with police as agents of the Aborigines Protection Board (APB), as census collectors and issuers of welfare (Goodall 1995). The racist roots of the Police Force were already well established at this point, and this new role (despite not delivering much more power to police at the time) is a certain reification of the role of police in NSW as front-line colonial agents with the purpose of subjugating Aboriginal people. Protectionism, especially insofar as police are concerned, is deeply a policy of paternalism and patriarchy. Beyond being agents of the Police Commissioner-chaired ABP, police officers took on roles far beyond that of conventional policing work. Cunneen and Libesman outline some of the abilities given by the Aborigines Protection Act 1909 (NSW), including the control over rations (determining, reducing, issuing, withholding and refusing them), removal of whole Aboriginal communities from localities, and removing children from families (1995, as cited in ALRC 2017, pp. 208-9). These extraordinary powers, which were indeed exercised, are at once paternalistic in their extreme constriction of Aboriginal peoples' freedoms and detailed control over how they lived and simultaneously patriarchal in terms of the gendered impacts of child removal, such as the inappropriate marriage of young Aboriginal girls to white men (Goodall 1995, p. 84). 
The impacts of the actions of police in removing children, or in any of their other patriarchal powers, have intergenerational repercussions such as trauma, over-representation in welfare systems, and poverty for the Aboriginal and Torres Strait Islander families who have been affected by them (HREOC 1997). The National Inquiry into the Separation of Aboriginal and Torres Strait Islander Children from Their Families heard many examples of such intergenerational effects, where mothers felt they had passed down negativity to their children (HREOC 1997, p. 222). The complexity of the way in which the NSWPF enact colonisation over Aboriginal people in New South Wales is shown here, where the act of removing a child from a family reproduces negative consequences in family lines without further police interactions even being required.

\section{The Aboriginal Legal Service}

The Aboriginal Legal Service formed in 1970 directly in response to the racist treatment of the post-World War II concentration of Aboriginal people in Redfern (Wootten 1993). The ALS provided legal advice and representation for Aboriginal people in Sydney, which was crucial in the legal enlightenment of Aboriginal people, as lawyers with specific knowledge beneficial to Aboriginal cases were few and far between. As an organisation, the ALS embodied self-determination and has been a positive initiative for Aboriginal and Torres Strait Islander peoples in NSW. However, it is the context from which this service arose as a means of preservation against police mistreatment (Wootten 1993) - that is perhaps most poignant. The organisation of Aboriginal people to fight the colonial actions of racist police officers in inner-Sydney became an organised voice for Aboriginal people, which spoke out against violence and racism (ALS n.d.).

Even after the establishment of the ALS, Cunneen shows a twenty-year period of regular complaints about the NSWPF and their heavy-handed, discriminatory approaches leading up to 1990 (1990, pp. 5-8). However, this problem is not unique to Redfern. Goodall uses NSW records to show the historic impact of economic downturns on how Aboriginal people were allowed to live their lives (1995). Stricter controls have been unevenly employed across the state depending on local economy and white hostility to government intention, regardless of the title of the policy of the day. Naturally, the Aboriginal Legal Service came to expand across NSW and into the Australian Capital territory, with the Western ALS breaking away from the initial body in 1977 to provide dedicated legal representation for the western half of the state (Cook \& Goodall 2013, p. 193).

\section{The Royal Commission into Aboriginal Deaths in Custody}

This Royal Commission was established in October 1987 in response to a growing public concern that deaths in custody of Aboriginal people were too common and public explanations were too evasive to discount the possibility that foul play was a factor in many of them. (Johnston 1991)

NEW: 2019 
This summarily and succinctly puts the reasons for the Royal Commission into Aboriginal Deaths in Custody (henceforth RCIADIC or the Royal Commission). Preceding the deaths of ninety-nine Aboriginal and/or Torres Strait Islander peoples in custody around Australia throughout the 1980s is 192 years of racist Aboriginal-Police relations.

One of the reasons for the RCIADIC's eminence is its focus on the big picture as well as on individual cases to illustrate a clearer image of Aboriginal deaths in custody and AboriginalPolice relations more broadly (Payne 1992, p. 67, Wootten 1993). In examining each of these ninety-nine cases and the circumstances surrounding them, the extent to which colonisation has marked the function of the NSWPF was revealed, further foregrounded by the Human Rights and Equal Opportunity Commission's National Inquiry into Racist Violence (1991), which found that 'Aboriginal-police relations [had] reached a critical point due to the widespread involvement of police in acts of racist violence, intimidation and harassment' (as cited in Wootten 1993, p. 291). Historically, this refers to the punitive expeditions led by police against Aboriginal people as frontier conflict (HREOC 1991, p. 39), and more recently to the Royal Commission, the twenty years of Redfern heavy-handedness shown by Cunneen (1990), as well as the deaths of Aboriginal and/or Torres Strait Islander peoples which renewed calls for the Royal Commission's establishment itself. All of these examples are tragic, yet clear cases of racist police violence.

One quantifiable outcome of a colonial police force exercising racist power over Aboriginal people is a disproportionate rate of incarceration. Wootten refers to the RCIADIC Criminology Research Unit's records of entrances and exits from police custody in August 1988, which shows that Aboriginal people were fifteen times more likely to be arrested than non-Aboriginal people in NSW, with Aboriginal women being extremely overrepresented nationally (accounting for half of arrests but constituting less than $1.5 \%$ of the population overall). Using different statistics, Wootten writes that, of all deaths in custody, Aboriginal people were twice as likely to die in police custody than their non-Aboriginal counterparts (1993, p. 279). Payne, on the other hand, is hesitant to rely on similarly ephemeral data in her discussion on Aboriginal women and the law, because there is a 'deficiency of conclusive statistics' to communicate the position of these women (1995, p. 66). Despite this, Payne is still able to show the way in which Aboriginal and Torres Strait Islander women across Australia have 'borne the brunt' of this country's colonial legacy in their interactions with the law.

\section{Implementations of the Royal Commission recommendations}

When the Royal Commission's Interim Report was published in December 1988, the NSW pitch for more funding to implement the recommendations included adding more police and bigger cells in areas with high Aboriginal populations, which Payne suggests would lead to increased prisoner numbers for Aboriginal peoples (1992 p. 69). As has been shown, this is the approach that had always been taken by the NSWPF and government: harshness and an 
absence of cultural understanding. Indeed, it wasn't until 1980 that the NSWPF ventured beyond the guise of 'equal treatment' to acknowledge Aboriginality with an Aboriginal Liaison Unit (Wootten 1993, p. 274). Ironically, police in NSW recognised Aboriginality from day one, with the colonial task first to kill Aboriginal people, all the way up to today with contemporary Aboriginal-Police relations (to be discussed below).

Once the five-volume National Report of the RCIADIC (the National Report) was released in 1991, the response by governments was to be assessed. Perhaps most significantly to this essay is Recommendation 60:

That Police Services take all possible steps to eliminate:

a. violent or rough treatment or verbal abuse of Aboriginal persons including women and young people, by police officers;

b. the use of racist or offensive language, or the use of racist or derogatory comments in $\log$ books and other documents, by police officers; and

c. when such conduct is found to have occurred, it should be treated as a serious breach of discipline.

(Johnston 1991)

That this recommendation had to be made at all raises many more questions about first 200 years of policing in NSW and Australia-wide altogether. This Recommendation was unanimously supported across Australia, and supposedly implemented in NSW by the then Police Service (Commonwealth of Australia 1992, pp. 203-4). Harvey suggests that, perhaps, the RCIADIC had envisaged a new model of policing based on this recommendation, with cultural awareness and cooperation with Aboriginal communities at its core (2012, p. 34), two elements which have been spoken of widely as essential to ameliorating policing in NSW (HREOC 1991, Wootten 1993, Payne 1992). In the twenty years between this recommendation's initial implementation and 2012, Harvey observes significant improvements in NSW in addressing police discrimination and racism against Aboriginal people (2012).

Another important consideration here is Recommendation 215, which speaks to the need for negotiation between Aboriginal organisations and police with regards to police activities (Johnston 1991). This recommendation sought to address the powerlessness felt by some Aboriginal and Torres Strait Islander peoples in the presence of police (Department of the Prime Minister and Cabinet 2018, p. 436). The implementation of this recommendation in NSW, however, is strongly critiqued by Wootten, who notes the 'grave reason to doubt that the Recommendation was understood, much less supported' (1993, p. 287). The implementation was Patrol Commanders involving historically white-dominated community consultative groups, with Aboriginal people of the Police Commander's choice. The actual effect of such an implementation left much to be accomplished in this field, and further reveals the lasting paternalistic nature of policing in NSW.

NEW: 2019 


\section{Contemporary Aboriginal-Police Relations in New South Wales}

How do we find Aboriginal-Police relations in NSW after 231 years of colonisation, racist policing, and decades after a milestone Royal Commission whose recommendations have been implemented in a contested manner?

Overrepresentation in the criminal justice system still plagues young Aboriginal and/or Torres Strait Islander peoples in this state, who are more likely than non-Indigenous young people to be dealt with by arrest, and more likely to be referred to court (Snowball 2008, as cited in Cunneen 2016, p. 37). This tells us that there is surely paternalistic heavy-handedness taking place in Aboriginal-Police relations today. Moreover, overrepresentation has continued to rise since the RCIADIC across Australia, with inappropriate measures being taken to address this issue (Crofts \& Mitchell 2011).

A repeated occurrence in dealings with the NSWPF is the use of drug detection dogs, which, beyond being ineffective, have been proven to increase drug overdoses and infringe on civil liberties (Hughes et al. 2017). That there is even a perceived discrimination against Aboriginal and Torres Strait Islander peoples in the exercise of this policy (Hughes et al. 2017, p. 64) is apposite to the ways in which a racist history of Aboriginal-Police relations has coloured contemporary interactions, with the expectation of marginalisation. Further research is necessary to definitively determine whether this perceived racism in the use of drug detection dogs is as real as it seems.

These two examples form a minor slice of the plethora of continuing negative outcomes in contemporary Aboriginal-Police relations. The result of such relations is an Indigenous incarceration rate which still expands rapidly, growing 25\% between 2013 and 2016 (Weatherburn \& Holmes 2017, p. 1). The state of contemporary relations is categorically shaped by the past, and the historical racism and paternalism which have manifested themselves in police interactions with Aboriginal and/or Torres Strait Islander peoples in NSW for centuries.

\section{Conclusion}

In closing, it is necessary to qualify the scope of this essay, which in no way seeks to make claims about all Aboriginal-Police relations. Instead, the focus has been on a variety of examples and histories which denote a systemic issue in the NSWPF, namely racism. The NSWPF have never been separated from their colonial genesis, and thus have been a continuing force of colonisation throughout the history of New South Wales. It is, however, important to acknowledge that there are police who work in the NSWPF who foster positive and beneficial relationships with Aboriginal communities, such as Inspector Fred Longbottom who believed in the right to protest and respected those who protested against injustices in NSW, and cooperated accordingly with the ALS (Wootten 1993, pp. 271-2).

NEW: 2019 
Also notable is Kevin Cook and William Bates' positive remembrance of Bill Galvin, who assisted in the hunting of bush tucker in Western NSW (Cook \& Goodall 2013, pp. 222-223).

Perhaps, in the case of the NSWPF, it is a question of good cops and bad cops; the fruits of a paternalistic orchard where, from roots in colonialism, trees with racist trunks stand. What is definite is the ongoing colonial aspect of the NSWPF. Within a settler-colonial justice system, enforced by a police force established to fit this system, the colonisation of Indigenous peoples living in NSW cannot truly end. Still, there is a need for further cooperation between the NSWPF and Aboriginal communities, both agents with tremendous capabilities to affect change, to improve the state of Aboriginal-Police relations (Department of the Prime Minister and Cabinet 2018, Wootten 1993, Scipione 2015, as cited in ALRC 2017 , p. 222). This will form a necessary step towards a reconciled New South Wales, where its police force can begin to ameliorate relations with Aboriginal and Torres Strait Islander peoples (Johnston 1991, as cited in Wooten 1993, p. 283).

\section{References}

Australian Law Reform Commission 2017, Incarceration rates of Aboriginal and Torres Strait Islander Peoples, Discussion Paper 84, ALRC, Sydney, $<$ https://www.alrc.gov.au/publications/indigenous-incarceration-rates-dp84>.

Aboriginal Legal Service n.d. History, ALS (NSW/ACT), Sydney, viewed 16 June 2019, $<$ https://web.archive.org/web/20171115035509/http://www.alsnswact.org.au:80/pages/histor y>

Commonwealth of Australia 1992, Aboriginal Deaths in Custody response by governments to the Royal Commission, Australian Government Publishing Service, Canberra.

Cook, K. \& Goodall, H. 2013, 'Part 3: Land Rights NSW 1980s', in Making Change Happen: Black and white activists talk to Kevin Cook about Aboriginal, Union and Liberation Politics, ANU E Press, The Australian National University Canberra, $<$ https://ebookcentral.proquest.com/lib/uts/reader.action?docID $=4585022 \& p p g=180>p p$ 175-204 / 235.

Cunneen, C. 1990, Aboriginal-police relations in Redfern: with special reference to the 'police raid' of 8 February 1990, Human Rights and Equal Opportunity Commission, Sydney, <https://www.humanrights.gov.au/our-work/aboriginal-police-relations-redfernspecial-reference-police-raid-8-february-1990-report>. 
Cunneen, C. 2016, 'Surveillance, stigma, removal: Indigenous child welfare and juvenile justice in the age of neoliberalism', Australian Indigenous Law Review, vol. 19, no. 1, pp. 32 45, <http://www5.austlii.edu.au/au/journals/UNSWLRS/2017/23.pdf>.

Crofts, T. \& Mitchell, T. 2011, 'Prohibited behaviour orders and Indigenous overrepresentation in the criminal justice system', Current Issues in Criminal Justice, vol. 23, no. 2, pp. 277-285, <http://www.austlii.edu.au/au/journals/CICrimJust/2011/31.html>.

Department of the Prime Minister and Cabinet 2018, Review of the implementation of the Royal Commission into Aboriginal Deaths in Custody, PMC, Canberra, <https://www.pmc.gov.au/sites/default/files/publications/rciadic-review-report.pdf>.

Goodall, H. 1995, 'New South Wales' in A. McGrath (ed), Contested Ground: Australian Aborigines under the British Crown, St Leonards, NSW: Allen \& Unwin, pp. 55-120.

Harvey, R. 2012 'Racist, offensive, and degrading police behaviour against Aboriginal people in New South Wales- modern challenges to the findings of the Royal Commission into Aboriginal Deaths in Custody', Australian Indigenous Law Review, vol. 16, no. 2, pp. 33-42, <http://www.austlii.edu.au/au/journals/AUIndigLawRw/2012/10.pdf>.

Human Rights and Equal Opportunity Commission 1991, Racist violence: Report of the National Inquiry into Racist Violence in Australia, Australian Government Publishing Service, Canberra, <https://www.humanrights.gov.au/sites/default/files/document/publication/NIRV.pdf>.

Human Rights and Equal Opportunity Commission 1997, Bringing them home: Report of the National Inquiry into the Separation of Aboriginal and Torres Strait Islander Children from Their Families, Commonwealth of Australia, Sydney.

Hughes, C.E., Ritter, A., Lancaster, K. \& Hoppe, R. 2017, 'Understanding policy persistence - the case of police drug detection dog policy in NSW, Australia', International Journal of Drug Policy, vol. 44, pp. 58-68, <https://www.sciencedirect.com/science/article/pii/S0955395917300816>.

Johnston, E. 1991, National report of the Royal Commission into Aboriginal Deaths in Custody, Australian Government Publishing Service, Canberra, <http://www.austlii.edu.au/au/other/IndigLRes/rciadic/>. 
New South Wales Police Force n.d. History, NSWPF, Parramatta, viewed 16 June 2019, $<$ https://www.police.nsw.gov.au/about_us/history>

Payne, S. 1992, 'Aboriginal Women and the Law' in C. Cunneen (ed.), Aboriginal Perspectives in Criminal Justice, Sydney University Institute of Criminology, Sydney, pp. 65-74, <https://aic.gov.au/sites/default/files/publications/proceedings/downloads/16payne.pdf $>$.

The Redfern story 2014, documentary, Ronin Films, Canberra, <https://uts.kanopy.com/video/redfern-story-1>.

Stanner, WEH. 1969, 'The Great Australian Silence', The 1968 Boyer Lectures: After the Dreaming, Sydney, ABC Enterprises, pp. 18-29.

Weatherburn, D. \& Holmes, J. 2017, Indigenous imprisonment in NSW: A closer look at the trend, Issue Paper 126, NSW BOCSAR, Sydney, $<$ https://www.bocsar.nsw.gov.au/Documents/BB/Report-2017-Indigenous-Imprisonment-inNSW-BB126.pdf>.

Wootten, H. 1993, 'Aborigines and police', UNSW Law Journal, vol. 16, no. 1, pp. 265-301, <http://www5.austlii.edu.au/au/journals/UNSWLawJl/1993/11.html>. 